\title{
Challenges of civil society organizations in tourism in Algeria: a civil participation approach
}

Les défis touristiques de la société civile organisée en Algérie : une approche sur la participation civile

Desafios da sociedade civil organizada no turismo na Argélia: uma abordagem da participação civil

Desafíos de la sociedad civil organizada en el turismo en Argelia: un enfoque de participación ciudadana

\section{Soufiane Boulassel}

\section{CpenEdition}

\section{Journals}

Electronic version

URL: https://journals.openedition.org/espacoeconomia/21202

DOI: 10.4000/espacoeconomia.21202

ISSN: 2317-7837

\section{Publisher}

Núcleo de Pesquisa Espaço \& Economia

Electronic reference

Soufiane Boulassel, "Challenges of civil society organizations in tourism in Algeria: a civil participation approach", Espaço e Economia [Online], 22 | 2021, Online since 13 January 2022, connection on 13 August 2022. URL: http://journals.openedition.org/espacoeconomia/21202 ; DOI: https://doi.org/ 10.4000/espacoeconomia.21202

This text was automatically generated on 13 August 2022.

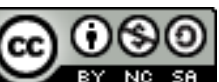

Creative Commons - Attribution-NonCommercial-ShareAlike 4.0 International - CC BY-NC-SA 4.0 https://creativecommons.org/licenses/by-nc-sa/4.0/ 


\section{Challenges of civil society organizations in tourism in Algeria: a civil participation approach}

Les défis touristiques de la société civile organisée en Algérie : une approche sur la participation civile

Desafios da sociedade civil organizada no turismo na Argélia: uma abordagem da participação civil

Desafíos de la sociedad civil organizada en el turismo en Argelia: un enfoque de participación ciudadana

Soufiane Boulassel

\section{Introduction}

1 The tourism sector is considered one of the most important businesses in the modern economy. In 2019, the travel and tourism sector contributed $10.4 \%$ to global GDP (WTTC, 2019). Today, tourism is the primary source of income and economic activity for many developing countries. It is a significant source of employment and has all the capabilities in contributing to the local community's livelihood. Tourism also has the potential in addressing socio-economic issues through sustainable tourism development.

Algeria, Africa's largest country by area, boasts many attractions that lend it undeniable potential as a tourist destination. Its long Mediterranean coastline, its distinct terrain between mountains, valleys, plateaus and the striking desert landscapes of the Sahara represents endowments that would make the country an attractive natural tourism destination. Besides, Algeria hosts important Roman, Islamic and Christian historic sites, seven of which are included on the country's UNESCO World Heritage list, such as Tassili n'Ajjer cultural park in the middle of the Sahara, the Roman cities of Tipaza and Timgad, and the Casbah of Algiers. In addition, the UNESCO 
recognizes eight seasonal festivals, traditional rituals and religious pilgrimages in its list of "intangible cultural heritage" practices. These coexist alongside Algeria's annual contemporary cultural offerings, centered in its largest cities of Algiers, Oran, Constantine and Annaba. However, Algerian tourism still suffers as the number of foreign tourists has not exceeded 3.5 million tourists annually for 20 years, and the number of arrivals to Algeria through travel agencies has not surpassed 2 million tourists per annum. In comparison, Tunisia reached out to 9.4 million and Morocco recorded 13 million visitors for 2019 (Trading economic, 2020).

This decline in tourism numbers in Algeria is due to a combination of interrelated obstacles that hinder the Algerian tourism development. These include, but are not limited to, the challenge of security, the lack of destination promotion and tourism culture. However, civil society organizations can act as problem-solving. Civil society organizations are considered the bridge between policymakers and citizens, and as such, they shall be strengthened to play an essential role in facilitating development. Clayton (1996) suggested that empowering civil society would lead to growth. Scholars believe that governments are not always in a solid position to execute good policies and programs for resource management. As a result, for various reasons, governments have shifted their approach from unilateral decision-making in the public domain to including a diverse range of stakeholders, such as private sector, government, civil societies and local people. Civil society organizations are playing an important role as they are regarded as legitimate and moral stakeholders in tourism development (Aref et al. 2010; Jamal and Stronza 2009; Tosun 2006). According to Muganda, Sirima, \& Ezra (2013), locals have to be involved in policy and decision-making to enhance their trust and confidence in the tourism industry. Moreover, the success of tourism development depends on the goodwill and cooperation of the local people. If their aspirations and capabilities are not compatible with tourism planning and development, it may jeopardize the potential of tourism industry. In that respect, scholars have for long argued that the involvement of civil society organizations in decision making can push economic development. However, in authoritarian contexts which are not conducive to the development and free functioning of an autonomous civil society, such claims have been refuted. Therefore, scholars argue that civil society organizations are often controlled and are more likely to ensure the durability of authoritarian regimes, rather than leading to a more open developed society.

Involving civil organizations in tourism management can have a number of advantages, including decreasing the load on government agencies, reducing conflicts, and increasing resource efficiency. Civil society organizations can be active in a variety of ways, from being consulted to playing a key role in planning and monitoring, and, in rare cases, being given the legal authority to manage resources. However, although the national strategy of tourism development in Algeria claims an important role of civil society organization in tourism development, their actual involvement still remains ambiguous. In this context, a critical issue is how effective civil society organizations are in managing the tourism sector in Algeria. This central problem embraces a set of sub-questions: (1) What are the real conceptual denotations on which associations in Algeria are based? (2) How capable are social societies' formations in performing effective roles in tourism development? (3) What are the prominent challenges and threats of civil society in Algeria? To answer these questions, this study seeks to investigate the reality of civil society organizations in Algeria by analyzing its legal 
context, institutional structures, the features of its elite and the latter's relationship with the state.

5 All this is through a theoretical and field study that seeks to identify the various obstacles that frame the reality of the civil society organization in Algeria. I conducted semi-structured in-depth interviews with 15 governmental and non-governmental institutions related to tourism in Algiers. The interviews have been made with leaders including sub-minister of tourism, head managers of tourism agencies, national federations and directorates, leaders of associations, and owners of travel agencies. The interview questions came to investigate the interaction of decision-makers in the tourism industry in Algeria. As part of the discussion, the interviewers spoke about the shortcomings that affect the tourism sector in Algeria with the role of civil society organizations. The interviewers indicated that the active involvement of different social actors through civil society organizations is essential for designing sustainable tourism strategies. Yet, in the case of Algeria, such organizations face many obstacles to their proper participation in tourism development processes, mainly because the state seeks to exercise exclusive power and control over them.

\section{Literature Overview}

\section{Civil society organization and tourism development}

6 Tourism is characterized by a multitude of stakeholders. Many products flows, transactions, and connections with other sectors such as health, education, culture, transport, etc., make it identified by a network of relationships with different parties. Hence, tourism development relies on the contribution of various parties with interests in the tourism sector and makes it their common responsibility. Freeman (1984) attempted to demonstrate social responsibility as it is not only limited to responsibility towards its part-owners but also includes responsibility to other parties, known as "stakeholders." In his 1984 book "Strategic Management: A stakeholder approach", Edward Freeman describes the organization as a set of relationships between its stakeholders, whom he defined as "any group or individual who can affect or is affected by the achievement of the organization's objectives" (p. 46). Stakeholders are distinguished by their relationships with various other stakeholders, such as owners, employees, clients, suppliers, lenders, and local society (Stoney; Winstanley, 2002). Nevertheless, the kinds of stakeholders can differ from one organization to another, according to its activity profile, economic sector, priorities, and interests between its entities. To ensure tourism development, all entities responsible for the tourism sector must be involved.

7 Civil society organizations are regarded as legitimate and moral stakeholders in tourism development (Haukeland JV 2011). Civil society as a notion is considered to date back to Aristotle, who defined it as a kind of society in which the state safeguarded civility. However, the modern understanding of the term came to represent the realm of solidarity and unity between individuals for a social good. In this context, civil society is defined as a group of organizations that arise from private citizens' initiatives, which does not aim to achieve profit, but primarily seek to achieve the public benefit (Ben Bayoub, 2013). It is also defined as the various voluntary organizations and bodies that are established under the free administration of its members with the intent of protecting and defending their interests, such as cultural 
organizations, professional unions, associations of all kinds, and non-governmental organizations (Aouchen 2010, p. 23). The connection between civil society and the social good was crystallized in the work of later liberal theorists, and particularly that of Alexis de Tocqueville. According to de Tocqueville, one of the benefits of civil society organizations was the chance they offered for otherwise vulnerable individuals to make their voices heard and compel the state to listen to their requests. In summary, they served as an "independent eye of society," monitoring the state and forcing it to behave in ways that benefited all sectors of society. In addition, de Tocqueville considered that participation in associations is the basic building block for democracy (Tocqueville, 1994).

8 However, Tocqueville's theoretical conception is not the only one. Antonio Gramsci made the argue that civil society is a field of ideological competition (Gramsci, 1971; Buttigieg, 1995). Gramsci says there are two main areas that ensure the stability of the domination of the ruling class. The first domain is the domain of the state, in which direct control, i.e., politics, is achieved. The second field is the field of civil society and all that it represents, such as parties, unions, associations, media, schools, churches or places of worship, etc., in which a second function is achieved, which is ideological and cultural hegemony (Green, 1993). According to Gramsci, the ruling class creates a hegemonic culture through ideology rather than by violence, economic power, or coercion. Hegemonic culture spreads its own values and conventions until they become "common sense" ideals for everybody, therefore maintaining the status quo. Rather than using force to preserve order, cultural hegemony is utilized to maintain consent to the capitalist order. The ruling class creates and reproduces cultural hegemony through the institutions that comprise the superstructure. Therefore, according to Gramsci, it is not enough to gain and maintain power to control the state apparatus, but it is necessary to achieve ideological hegemony over society (Gramsci, 1971; Buttigieg, 1995).

Nevertheless, contemporary theories have demonstrated the importance of civil society as a mechanism for achieving development in all the political, economic, social and environmental fields. Hence, it can be considered one of the main pillars for achieving progress and activating development, especially in light of the inability of the state alone to meet the needs of society, in addition to the problems that the individuals suffer from. There are various forms of development, including comprehensive national and local development, and all societies seek to achieve development in all its forms, which implies a direct relationship between civil society and sustainable local development.

10 The degree of involvement of locals in various decision-making and policy issues is determined by the extent to which they affect or are affected by these decisions and policies. Pongporant (2011) noted that "local tourism development requires people who are affected by tourism to be involved in both the planning process and the implementation of policies and action plans." (p. 60). Many researchers believe that the contribution of civil society organizations in planning for tourism development helps better understand local development processes, preserve the environment and maintain sustainability (McIntyre et al, 1993; Muhanna 2007; Aref et al. 2010; Pongponrat, 2011). Furthermore, tourism is a service product, so the quality of service is related to the quality of the environment and the conditions in which it is provided. Thus, good coordination with locals, framing and directing their behaviors contributes 
to improving the quality of tourism, and an increased satisfaction of the local community with the authorities and the government in general, as a result of a sense of the state's readiness to hear their views and put forward a change that is in line with their requirements (Mason, 2015).

Theoretically, the role of civil society in tourism development in terms of policy and decision-making is dependent on the kind and level of participative approach used within a tourist destination. According to Mannigel (2008) there are different levels of participation ranging from simple sharing of information to a full transfer of power and responsibilities. The power of civil society to influence decision making as well as policy making will therefore depend on the level of participatory approach being in operation in a particular destination. There are several examples of successful collaboration between local communities and other stakeholders. In a research conducted in Costa Rica, for example, Matarrita-Cascante et al. (2010) found that participation was represented at many levels, ranging from local engagement in community meetings (involvement) through the ownership and administration of local resources. Local communities were able to actively influence changes in their region as a result of such a diverse engagement. A study by Williams, White, and Spenceley (2001) on two community tourism organizations, one in Uganda and one in Namibia, showed that the role of associations is to assist tourism businesses to become "self-sufficient and independent while contributing towards the development of the local community" (p. 2). In most of the developing countries, however, decision-making and policymaking process is generally top-down, with the dominance of the government and/or the private sector. The ability of local population to influence decision-making and demand their legitimate share in such an imbalanced situation is unclear. Their engagement arguably cannot go beyond simple consultation and information sharing (Scherl and Edwards 2007).

12 In general, governments follow different strategies in dealing with civil society organizations depending on the context. A valuable study that looked at the politics of the relations between states and civil society in Africa, suggests that despite the variation in contexts between African countries, governments used relatively similar methods to control civil society organizations (Bratton 1989). These strategies included monitoring, coordination, co-option and dissolution. Monitoring is often accomplished by controlling the registration procedure for civil society organizations and collecting records and information about their operations. Governments in Somalia, Ethiopia, and Zimbabwe, for example, require annual reports on their operations. In some cases, governments claim that the activities of civil society organizations do not match the government plans, for which they had to be coordinated or stop their work. However, in other cases, co-option is a widely used strategy where governments find ways to make civil society organizations become part of the regime. In Tanzania, heads of civil society organizations are usually part of the government. In addition to these, the strategy of dissolution is usually the shortest way for governments to deal with civil society organizations especially during times of high political tensions, as observed in Zimbabwe and Ethiopia.

However, these forms of behavior have had a massive effect on the role of civil society organizations and hindered their work for social, political and economic development. According to Kelsall (1998), civil society cannot perform well in many developing countries due to continuous state attacks against civil society organizations. The severe 
challenges faced by these organizations deemed their valuable contributions and demotivated society in playing a vital role in development. In this context, this paper investigates the actual contribution of civil society organizations to tourism development in Algeria and analyzes the obstacles they face.

\section{The reality of civil society organizations ("Associations") in Algeria} promulgation of the French law in $1901^{1}$ (Northey, 2017). However, the process of establishing associations became active in Algeria in the early 1930s (Bendimerad, Chibani and BOUSSAFI, 2019). The emergence of associations in Algeria during the colonial period was one of the most crucial steps for the Algerian freedom movement to consolidate the features of the Arab-Islamic culture in the minds of Algerians and to retain youth from assimilating into the French culture. The best example of associations at that time was the Algerian Brotherhood Movement, formed by Prince Khaled on January 23, 1922, and the Association of Muslim Scholars, established on May 05, 1931. Because of their suspected role in mobilizing people against colonialism, these organizations were placed under close scrutiny. In fact, the colonial administration in Algeria issued a decree in January 1938 to limit the associations' activities. In an official report of 1954 on associations, the French administration described Algerian associations as a real danger due to the significant role they played in reviving the landmarks of national Islamic identity (Chaouch, 2015). Therefore, the freedom to establish associations in Algeria was subject to two different regulations, one for French citizens and the other for Algerian Muslims (the locals), and the difference between them was clear. While freedom of association was recognized for French citizens, it was forbidden to Algerian Muslims, and they had to obtain a permit for every gathering whatever simple it was, including marriage celebration (Maouchi, 2020).

After Algeria gained its independence in 1962, the philosophy of political power settled on establishing a solid and stable state (Northey, 2017). The country's constitution issued in 1963 stipulated that the state guarantees freedom of association (Maouchi, 2020). However, the National Liberation Front or FLN (the ruling party) was obstructing and banning all forms of independent popular organization. In a 1964 conference, the Liberation Front Party declared that the only legitimate representative of society is the FLN, the plurality of parties is not in itself a measure of democracy or freedom, and that the variety of visions can negatively impact the common interest of the people (Chaouch, 2015). As a result of this political conviction, the Ministry of the Interior issued an instruction in March 1964, launched a judicial investigation on all authorized associations whatever the nature of their activities was with the aim of finding out the true goals they seek to achieve and the activities they carry out. In practice, this instruction became a tool to grant a license to establish an association (Chaouch, 2015).

In 1971, Algeria issued the first law of associations. Law 71-79 defined the association as: "The agreement whereby several persons, permanently, and by participation, submit their knowledge, activities, and material means to work within a defined framework that does not generate profit" (Law 71-79). This definition came in the context of the ideological trend that was soaked in socialist ideas. The law considered associations a threat to national cohesion since they appeared competition to the state (Northey, 2017). This period was featured by the dominance of the state over society, as 
associations were used to control society to achieve and embody the official ideology. All the associations produced in that period were affiliated with the authority, including the National Organization of Mujahideen (ONM), the National Union of Algerian Youth (UNJA), the National Union of Algerian Women (UNFA), the National Union of Algerian Farmers (UNPA), the General Union of Algerian Workers (UGTA) (Chaouch, 2015).

17 In 1986, Algeria went through an economic crisis. This showed the fragility of the national economy and disrupted the major political plans adopted by the government. Hence, the Algerian political leadership tended to neglect economically non-vital sectors such as the social, cultural and sports sectors and leave them to associations in order to alleviate the burdens on the authority. Accordingly, the 1986 charter encouraged the establishment of scientific, cultural and professional organizations, followed by Law 87-15 which was considered the first step into the freedom of establishing associations. The new legislative reform eased many restrictions on forming associations, which gradually multiplied and varied. The Ministry of Interior estimated the number of associations in that period at 11,000 association (Azaoui, 2014).

However, the deterioration of the political, economic and social situation of the country led to the explosion of the security situation. The October 1988 riots $^{2}$, a series of violent demonstrations by the Algerian youth, were a fierce attack on the authority. Demonstrators raised questions about the state's strategy, and even the legitimacy of the regime. The weakest point of the regime was its loss of legitimacy, especially since its traditional base, its "historical and revolutionary prestige" had become meaningless by the late 1980s to the majority of young people. The riots indirectly led to the fall of the country's one-party system and the introduction of democratic reforms. Historian Mohand Arezki Farrad described the events as Algeria's early bird Arab Spring (Aljazeera Reports, 2019). These events led to the approval of a 1989 constitution that was in line with the country's new phase, and Algeria approved for the first time the partisan pluralism, freedom of expression and the emergence of a (relatively) independent press (Northey, 2017).

In the context of fundamental transformations, the constitution also made room for civil society to flourish. In 1990, the law 90-31 introduced new provisions for associations, opening the way for the establishment of (non-political) associations of all kinds of activities, e.g., social, religious, educational, cultural and sports-related. During this period, Algeria witnessed the birth of a large number of associations. In 1996, statistics counted 778 national associations, and 42,116 local associations. Four years later, there were approximately 1,000 national associations and 56,500 local associations (Azaoui, 2014). And according to December inventory of 2010, the number of associations reached 1,005 national and 88,700 local associations (Chaouch, 2015). However, although the numbers suggest the emergence of an authentic, active and strong civil society, those associations in reality remained weak and largely dependent on the state (Northey, 2017).

In any case, the law 90-31 of associations continued to work until the beginning of the Arab Spring. The uprising of anti-system protesters shook the Algerian government. Thereafter, the authority was quick to amend a number of laws, most notably the law of political parties and the law of associations. In this context, Law 12-06 of January 15, 2012 was issued, which defined associations "as a gathering of natural or legal persons on a 
contractual basis for a specified or unlimited period. These persons participate in harnessing their knowledge and means voluntarily and for a non-profit purpose for the sake of social, scientific, religious, educational, cultural, sports, environmental, charitable and humanitarian activities" (Law 12-06). Although it seems from the first reading of this law that it came to enrich the old law of associations, but in fact the Algerian legislator sought to tighten control over the associations' work (Human Rights Watch, 2014). The law defined a set of arbitrary requirements that must be met to establish an association, imposing thus several obstacles to civil society organizations that will be addressing in the results of the research.

Nowadays, Algeria has 180,940 associations in 48 provinces [Fig 1]. Algiers as the capital city hosts a large number of them, with 11,692 association in different domains. The number of tourist associations is calculated at 1086, which represents only $1 \%$ of the total number of associations and most of them are concentrated in the northern cities, within the broader region of Algiers, due to the lack of means and material capabilities and the weak education structure in Algeria's southern part in the Sahara desert.

Figure 1: Associations in Algeria by thematic focus, 2020; and figure 2: The share of associations in Algeria by compatibility with the law, 2020.

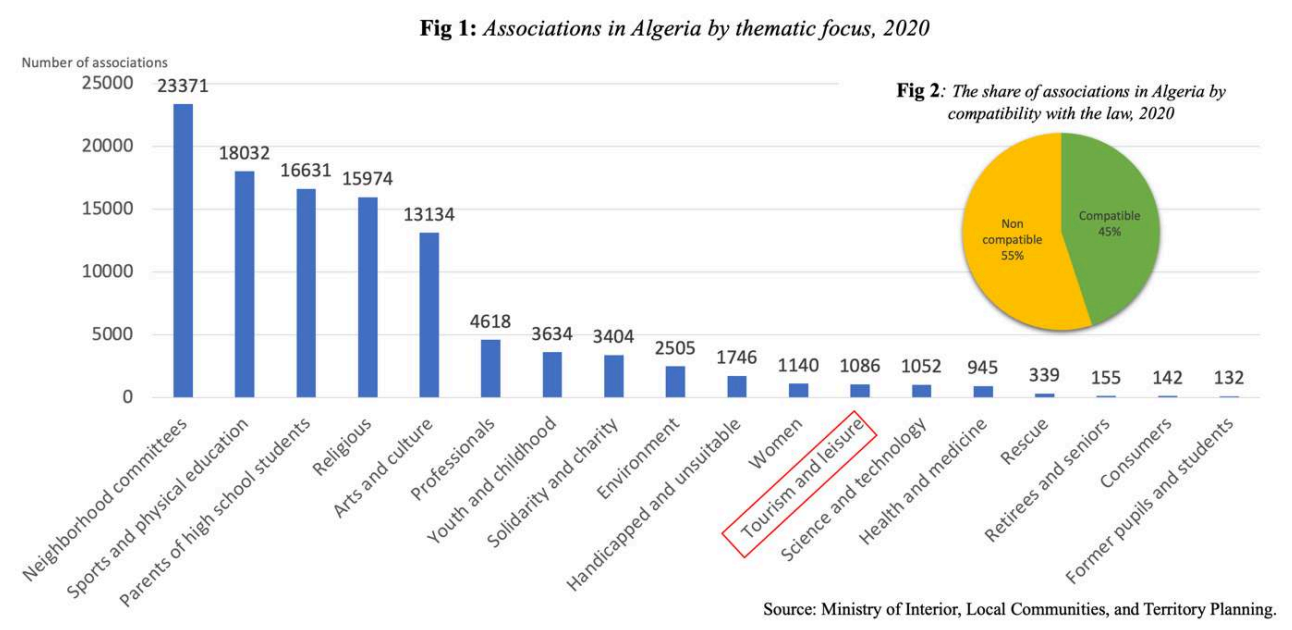

Source: Ministry of interior, Local communities, and Territory Planning

The first thing that reflects the condition of civil society in a country is the sheer number of associations. However, in the case of Algeria, this figure does not reflect the actual performance of these institutions in reality. First, $55 \%$ of all associations in the country do not follow the rules of association law, implying that less than half of them is legitimate [Fig 2]. Second, in general, the effectivity of civil society in Algeria has long been restricted by that the state does not view it as a partner in development that complements the shortcomings of the state, but rather considers it as a competitor that must be curbed. In fact, civil society institutions in Algeria are exposed to many obstacles that make them unable to sufficiently play their developmental role in general. Therefore, it is critical to identify the obstacles that are hindering the proper work of tourism associations in Algeria. 


\section{Research Methods} participation and power that are intangible and more complex, sensitive and or difficult to quantify using more traditional quantitative research methods. Therefore, an interpretive paradigm was adopted, and a qualitative research study was conducted based on in-depth interviews. The interviews were open-ended and semi-structured in order to give participants a high level of autonomy in describing their role and relationship with the state, while still offering consistency across themes and strong cross-checking potential. The sampling strategy was to select fifteen governmental and non-governmental institutions related to tourism at the national, regional and local levels in Algiers, the capital of Algeria. The reason for choosing Algiers was to ensure geographic coverage as it considers a focal point of national decision making and the space of a large variety of stakeholders.

Before starting with the research methodology, it is important to highlight some obstacles and difficulties that emerged at the first stage of the research. It was difficult to locate the headquarters and official addresses for some of the tourist authorities, prompting me to launch a local inquiry to locate their office in order to explain the study aims and schedule an appointment. Sometimes a single appointment took more than three visits to the same institution before I was granted permission to conduct the interview. I also encountered bureaucratic obstacles and the difficulty of reaching some officials without the aid of a third party. Some organizations asked me to leave an official meeting request at the reception desk; nevertheless, the authorities did not give me a document deposit receipt. Also, some responsible people were afraid that the information requested would be used for political purposes, especially with what the country knows of protests against the ruling authority, which began in February 2019, denouncing the fifth term of President Abdelaziz Bouteflika. Therefore, some interviews were not audio-recorded in case the interviewees expressed their willingness to participate in the research but did not consent to audio recording. In these cases, I made written records instead.

The participants were chosen through a targeted sampling method among the president and managers of prominent governmental and non-governmental institutions. Yet, the interviews between both types of institutions were justified in terms of ensuring a comparison of otherwise heterogeneous views and enabling each party's approach to be equal during the analysis, since intensive description and purposeful sampling help make decisions more systematically and transparently. Interviews ranged in length from 20 to 60 minutes, with the average interview lasting for 50 minutes. As a 27-year-old local researcher student, I am well aware that accessing a governmental organization in Algeria requires at least a pair of long pants, therefore a business casual outfit was necessary.

I described myself as a PhD student at an international university and described the study as part of my doctoral research project that seeks to understand the role and challenges of tourism stakeholders in Algeria. I also mentioned that the interviews will be only used for the purpose of research. The interviews were carried out in Arabic, "the Algerian dialect", they were analyzed and later translated into English. The interviews were conducted to clarify issues arising from my previous studies. I started the conversation asking the interviewees to briefly introduce themselves, their 
positions and background. I used an 'interview guide,' addressing key themes about sustainable tourism in Algeria, participation and stakeholder involvements in tourism developments. As part of the discussion, the participants were investigated about their awareness of local community and the role and function of associations, followed by questions on the challenges they might face, and their opinion on the institutional agency that could help implement tourism in the national scheme.

The main body of interviews took place between July 2019 and September 2019. When all interviews were completed, they were literally transcribed. Thereafter, a systematic in-depth review was carried out on a line-by-line basis. "In vivo" codes, derived from the words/phrases used by interviewees, dominated the coding strategy. Coding in this manner guaranteed that the data drove the analysis. The number of interviewees that raised a certain code was counted to determine the most prevalent themes arising from the data and their frequency among responders. Quantifying qualitative data in this manner lowers the risk of researcher bias and increases the study's robustness.

Moreover, data was consolidated and explored in more detail using content analysis, and particularly relevant extracts. At the local level, most comments were associated with the law of associations, the sources of funding and non-key intervention imposed by the state to the work of associations. In this context, I have conducted a critical analytical study of the law of association of 2012 "12-06" in comparison to the old law of 1990 "90-31". I tried to highlight the obstacles faced by associations in terms of incorporation, activity or control imposed by the state. The 2012 law contains 74 articles divided on 6 chapters. For analysis, these articles were divided into 3 sections. These sections were discussed in 3 stages: articles related to (1) the conditions for forming associations, (2) the financing and properties of associations, and finally (3) the duties of associations, as well as their suspension and dissolution.

Furthermore, interviewees mentioned bureaucracy and marginalization, which is due to the absence of democracy. Meanwhile, at the top of the authority pyramid, decisionmakers mostly referred to the mentality of civil society as a reason for the failure of associations, which they claimed to mix up the concept and role of associations and political parties, in addition to the absence of political culture and the infringement of the law by associations. Here, I focused on a critical analysis of the literature collected around the topic. I translated the information, facts and concepts passed by stakeholders into keywords. These keywords have been encoded and interpreted in such a way that it can be used to learn about civil society. All these elements came consistent with the reality of civil society in Algeria.

\section{Findings}

Tourism stakeholders have expressed their views on the failure of civil society organizations in Algeria. The resulting points explaining either this failure or the nonparticipation of tourism associations in the tourism scheme in Algeria identified three main reasons: (1) legal barriers; (2) political obstacles and (3) socio-cultural factors.

\section{Legal barriers}

31 The right to establish associations is among the rights enshrined in the various Algerian constitutions. Since its independence in 1962, Algeria has known 3 laws of associations starting from the law 71-97 of 1971, the law 90-31 of 1990 and the law 12-06 
of 2012, which consider the last and the most important associations law introduced after the Arab Spring of anti-government protest. The Algerian government claimed that the new 12-06 law of 2012 came under the Algerian government's reforms to free the associations. However, legislators confirmed that the new law sought to tighten the procedures for establishing associations and impose tight control on their activities and financial resources, which negatively reflected the creation and performance of associations in Algeria (Ben Nasser, 2014). During the interviews, interviewers agreed that the current law is stricter and more restrictive for associations; while it is supposed to be more open, one of the interviewers confirmed the harsh law against associations, as follows:

"The association law in Algeria was changed when the winds of the Arab Spring blew. Does this tell you anything? ... the old law was removed under the banner of reforms and giving more freedom to associations, but in reality, a more stringent law was adopted!" (Assoc 1).

These claims led me to investigate the law of associations in Algeria, that establishing excessive registration requirements that are subject to broad bureaucratic discretion; limiting or excluding foreign funding; permitting improper state interference in the internal affairs and operations of civil society organizations explained as follow:

\section{Registration Requirements}

Law 12-06 of 2012 stipulates that associations must obtain a registration license from the authorities before proceeding legally. Yet, the law states that the authority can refuse to register an association if the association's program and its associated activities are inconsistent with "national principles, values, public order, public morals, and the provisions of applicable laws and regulations" (Law 12-06). According to researchers, these standards provide the authority with a significant margin to hinder the recognition of any association (Ben Nasser, 2014). Interviewers have acknowledged the unfair procedure to establish an association in Algeria, describing it as a lengthy, difficult procedure, and in most cases, a positive outcome is never guaranteed.

The procedure for establishing and registering an association is extremely difficult. If you decide to create an association, you will find yourself in a huge procedure. The establishment of our association required nearly a year of continuous and diligent work". (Assoc.2)

34 A critical analysis of the law reveals further restrictions limiting associations' role in Algeria, starting from the number of founding members required to form an association. The Algerian law requires between 10 to 25 founding members representing at least 12 provinces for a national level association and 3 provinces for a local-based association (Law 12-06). Previously, law 90-31 of 1990 required only 15 members to establish a national or local association (Law 90-31) without specifying their place of residence. Although, some analysts saw this point as a positive point from which the Algerian legislator seeks to preserve diversity in associations (Ben Nasser, 2014). It has also translated into another obstacle that limits the creation of associations and imposes on the founding member a communication network that includes 12 out of 48 states in the case of national association.

Moreover, establishing an association requires a permit to form a public meeting to approve the association statute. Following the provisions of Law 89-28 of December 31, 1989 on public meetings and demonstrations, the statement of the meeting must be 
signed by three persons who live in the concerned community and enjoy all their civil rights, and the deposited declaration must indicate the purpose, date, time, duration of the meeting and the number of participants with all their names and addresses. This itself constitutes another barrier as one of the interviewers says:

"Yes, the law requires to hold a "plenary session" to approve the association's statute. Holding this session in a hall, public lectures, or other public place requires notifying the authorities in advance! Those are useless conditions that only disrupt the process of forming an association."(Assoc. 2)

In addition, the law also insisted that the statement must be deposited at least 3 days before the date of the meeting at the governor of the state concerned. Though, the state government has the right not to accept the meeting or to accept it under conditions of changing the place and/or time or can even send a delegate to supervise the proper functioning of the meeting. All these conditions operate as an additional filter to determine the outcome of an application (Ben Nasser, 2014).

Furthermore, the establishment of an association is subject to submitting a constituent declaration attached to the association's registration application to the Municipal People's Assembly for local associations, the province for regional associations, and the Ministry of the Interior affairs for inter-regional and national associations. Article 8 of 12-06 law stated that the relevant administrative authority must issue a registration receipt once an association submitted their application. The law does not allow the authorities to refuse to accept documents or issue the receipt (Law 12-06). According to law, the administration has a specific period of time to decide on allowing the registration. This period has a deadline of 30 days in the case of local associations, 40 to 45 days for regional and inter-regional associations, and 60 for national associations. The law states that when the deadlines elapsed without objection, the association can proceed to work legally. Therefore, the issuance of that receipt is considered the beginning of the review of the association's registration. In practice, however, the authorities often break the law and refuse to provide a receipt when the association founders submit their registration documents. Interviewers confirmed that

"The authorities can refuse to register an association if they decide that the content and objectives of its activities are inconsistent with "national principles and values, public order and applicable laws." ... Some associations have agendas that the authorities do not like, so the authorities did not provide them with a registration receipt and deprived them of getting evidence of the date of the fulfilment of registration requirements." (Assoc.1)

Additionally, following Articles 10 and 11, if the application gets rejected by the authority, the association can resort to court. If it wins the case in the courts, the law still stipulates that the government has a three-month period to cancel the creation of the association again. This concession granted to the administration is hindering the procedures of forming associations and provides the government with the necessary means to limit the number of associations.

As for the establishment of foreign associations, the Algerian legislator elaborated a special system for their establishment. The Algerian legislator has subjected the request to establish a foreign association to the prior approval of the Minister of the Interior, who takes the opinion of the Minister of Foreign Affairs and the Minister in charge of the sector where the association wants to operate. This is in addition to the condition included in Article 63 of the same law, which requires the existence of a formal agreement between the Algerian government and the government of the country of origin to which the foreign association belongs, which aims to promote 
relations between the two peoples (Law, 12-06). All these conditions and procedures are obstacles to limiting the formation of foreign associations (Hanafi, 2020). These obstacles are deeply rooted in Algerian politics and the fear of foreign interference in the country's internal affairs or compromising national sovereignty. Even the opposition leftist Ramadan Tazibt, a deputy of the Workers' Party, approved the government's decision to prevent any funds coming from abroad for the benefit of Algerian associations. He said that associations have benefited from foreign funds and have become demanding autonomy, referring to the movement for autonomy in the Algerian Kabylie region, founded by the political activist and singer Farhat Mhenni, residing in Paris (France 24, 2011).

\section{Funding Restrictions}

40 The ability of associations to access financial resources is a vital part of the right to freedom of association. Yet, the limitation or prohibition of foreign funding in Algeria is considered one of the harsh decisions against civil society organizations (Hanafi, 2020). Decision makers express their dissatisfaction with the restriction or prohibition of foreign funding in Algeria saying:

"We have limited sources of funds for touristic activities. Charities have better sources of money than we do.... Member subscriptions are only symbolic amounts, external funding sources are limited, and state subsidies are weak. This is why our activities are few. " (Assoc.2)

"The state imposes cumbersome procedures on associations to obtain a license, forcing them either to operate on the periphery of the law or give up the foreign grants they need to operate effectively." (OLT)

41 The sources of funding for associations in Algeria are mentioned in article 29 of law 12-06. These resources are the contributions of its members; the income associated with the association activities and their properties; cash and in-kind donations and wills; and subsidies provided by the authority (Law, 12-06). Interviewees have agreed that the lack of resources makes the association's activity falling short of the required level. Based on the law, the subsidies are granted only based on a program contract that is compatible with the objectives of the association and the rules of the public good. Also, granting subsidies should take place only after presenting a program of activities and its approximate costs, under the condition of sending a file of any previous subsidies, and it should similarly reflect the conformity of the expenses awarded for the activities carried out (Law 12-06). In addition, the association's accounts are subject to permanent monitoring and accountability (Law 12-06). This may justify the state's keenness on the rational and efficient use of public funds to avoid the use aside from activity and subject matter. Still, it justifies the measures that would control the use of association funds and activities (Hanafi, 2020). The study of Chaouch (2015) confirmed that the financial support provided by the government to support civil society organizations is only afforded to some associations based on the equation of distance from the concepts of the ruling system (Chaouch, 2015). This financial support is seen to be a soft way to keep the "civil society organizations" subordinate to "the authority" (Ben Nasser, 2014).

Moreover, it is prohibited by Algerian law for any association to obtain funds received from foreign organizations, except for those resulting from legally-established cooperative relations (Law 12-06). All interviewees acknowledge that funding 
restrictions significantly limit the work of associations in Algeria. One of the interviewees said:

"The old law allowed Algerian associations to accept grants from foreign organizations if the authorities agreed to their request. Law 12-06 added another condition, stating that associations are prohibited from receiving donations, except for those resulting from legally established a prior cooperative relationship."

(Assoc.2)

For comparison, the old law 90-31 of associations allows associations to accept grants from foreign organizations if the authorities agreed to its demand. The demand counted as the one and the only procedure that must be done to grants foreign funds and allow transactions. However, the new law 12-06 added another condition to limit Algerian associations from receiving funds from foreign associations. Accordingly, law 12-06 clarifies that the association must first obtain approval for a cooperation agreement with a foreign party without including any financial provisions. Then, likewise, the financing agreements that come after the cooperation agreement are also subject to approval from the competent authority, and the transaction form must include a description of the project to be funded; budget estimates allocated to finance the project; methods of payment; human and material resources allocated to complete the project. This is in addition to other provisions that the Algerian legislator defines as non-specific (Law 12-06).

That is clearly evident that discretion is often used cleverly to withhold or tacitly deny funds (Hanafi, 2020). Perhaps the main reason for the Algerian legislator's fear of aid provided by foreign associations stems from the political situation in neighboring countries, especially after the anti-government Arab Spring protests. Or perhaps the foreign associations' interference in Algerian internal affairs is the reason why the Algerian legislature is tightening the work of foreign associations with special law articles whether in terms of establishment, activity or obtaining financial resources (Ben Nasser, 2014).

\section{Operational restrictions and interference}

Independence of association is an important pillar to advance the role of local communities (Aref et al. 2010). Yet, it is barely provided in the case of Algeria. Except for the restrictions mentioned above, state authorities interfere in the internal affairs of civil society organizations through a combination of procedures (Ben Nasser, 2014).

Law 12-06 stipulated a set of conditions for founding members. Natural persons who can establish, manage and run an association must be 18 years of age or older, and of Algerian nationality. They have to enjoy full civil and political rights, and they must not have been convicted of a felony or a misdemeanor inconsistent with the association's activities. However, some conditions lack a precise legal definition, whereas some others are unclear and impractical. For example, the Algerian legislator has stipulated Algerian citizenship and has not specified whether it is original or acquired nationality. Likewise, for the condition to enjoy all civil and political rights, the Algerian legislator has neglected an important category in society. The question here is, why people who deprived of their political rights has no right to establish associations? The legislator in the same law and the provisions of Article 13 recognized that the associations' purpose, name, and work is distinguished from political parties, and they cannot have any relationship with each other, whether organizational or 
structural. Besides, associations cannot receive subsidies, donations, or bequests from any political parties, whatever its form is. As long as the law demands a separation between political action and associations, citizens cannot fully enjoy their political rights to establish associations.

Moreover, during the interview, the interviewees admitted the extent of monitoring and interference practiced by the authority on the work of associations starting from monitoring the bank accounts of associations to imposing criminal penalties against them if they did not comply with the articles related to the association's law, especially the articles related to the obligation to inform the competent authorities when holding public meetings, the obligation to submit copies of meetings and financial reports to the authority, as well as the penalties for obtaining foreign cooperation within the framework of agreements outside the law. As one of the interviewees stressed:

"The obligation to extent reports to government organizations and the continuous control of financial resources impose onerous obligations on associations and it is a form of undesirable intervention." (Assoc.1)

According to law, it is obligatory to inform the administration of any amendment to the rules and/or any change in the executive bodies of the association within 30 days from the date of taking the decision (Law 12-06). In addition, associations must send a copy of the meeting details and a copy of the financial and literary report to the authority after each general assembly, within a maximum period of 30 days from the date of approval. If the association refuses to deliver these documents on time or fail to inform the authority about any changes within the association, the association will be punished with a fine ranging between 2,000 and 5,000 Algerian dinars (DZD), around 10 to 25 euros, a significant amount compared to the minimum wage in Algeria, which is 20,000 Algerian dinars, roughly 100 euro, per month. However, this fine is another form of indirect interference in the activities of associations and a step to increase the state's dominance around association's (Meghzili, 2017).

Besides, the use of the association's resources for purposes other than those for which it was established leads to suspending or withdrawing the association's license permanently. Furthermore, every member active in an association who is not registered or approved shall be liable to imprisonment from three months to six months and a fine of 100,000 to 300,000 DZD, around 500 to 2000 euros. Nevertheless, the state official's interference in the day-to-day running of associations imposes unnecessary hardship on associations (Hanafi, 2020).

\section{Political obstacles}

The goal of civic engagement is to address public concerns and promote the quality of the community. Associations in Algeria are suffering from a massive defeat. Interviewees stated that the most common reason for the failure of associations stems from political issues, most commonly the absence of democracy, marginalization, bureaucracy and political unwillingness to develop the tourism sector.

\section{Absence of democracy}

51 The link between associations and democracy is an important dimension (Northey, 2017). Democratization theorists have argued that civil society organizations can be a way of promoting democratic values and increasing freedom in the political arena. In 
fact, real democracy depends on the crucial role of civil society institutions as intermediary channels to facilitate political participation. Alexis de Tocqueville confirmed that associations in the USA in the nineteenth century played a fundamental part of American democracy (Tocqueville, 1994). Cavatorta and Durac (2011) explain that civil society has broadly been seen as good for democracy as it promotes the interaction of people in a voluntary setting, where differences of opinion have to be taken into account.

Nowadays, the battle for the development and liberation of civil society is at the same time a battle for the consolidation of democracy (Ben Nefissa, 2002). Former SecretaryGeneral of the United Nations Ban Ki-moon emphasized the role of civil societies as follows: "If leaders don't listen to their people, they will hear them in the streets and squares, or, as we often see now, on the battlefield. There is a better way. More participation. More democracy. More engagement and openness. This means providing the maximum space for civil society organizations" (UN, 2013).

The interviewees expressed a gap between civil society organizations and the authority, which is mainly linked to the lack of democratic principles and political and civil freedoms. It is not new to speak about the lack of democracy in Algeria. Historically, in 1962, Algeria gained independence from France, in which the National Liberation Front (FLN) played an important role. But the political scene was reserved only for the FLN as a single political party. Under the stress of rolling back the colonial state, nation-building did not always permit autonomous organizations. Ben Nefissa (2002) writes that the construction of modern states after independence was a period of rupture for associative life in Arab countries. In the Algerian case, as Addi (2011) argues, the need to unify the nation after the war of independence meant there was a "refusal to accept politics and conflict" and a denial of plurality. In the Algerian case, Derras (2007) explains that the state established associations expecting them to provide unconditional support for the system in order to control and manage society. This period was dominated by a single political party and little freedom of association.

Nevertheless, after the October 1988 riots and the new constitution of 1989, Algeria was seen as a model for democratic transition in the developing world (Terranova, 2011). The reformed laws regarding associations, a (somewhat) multiparty framework and the freedom of political speech aimed to change the authoritarian regime into a liberal government. However, although some of the democratic practices were implemented during the transition period, this democratic transition regrettably did not come to a profound realization (Rahal, 2017), mainly because the Islamic political party FIS rejected Western influence into Algerian society, especially democracy, and tried to run on a platform of Islam tradition (Terranova, 2011). The defeat of the ruling party FLN by an Islamic opposition resulted in a civil war from 1990 until 2000 between the Algerian government and armed Islamic groups, ending in the deaths of an estimated 200,000 Algerians.

Between December 2010 and March 2011, Algeria experienced again a significant unrest. In the wake of the protests calling for reform in Arab countries (the Arab Spring), President Bouteflika promised in April 2011 to implement comprehensive reforms, including amendments to the constitution, laws related to elections, political parties, associations, and the media. However, the new Associations Law, adopted by the Parliament in January 2012, was a step backwards concerning freedom of association. Therefore, Human Rights Watch wrote that the Algerian authorities use the 
2012 law of associations "and sometimes exceed it" to limit the formation of associations. The power arbitrarily refuses to perform association registrations, putting new and old independent organizations in a legal dilemma and restrict their ability to obtain foreign funding or hold public meetings (Human Rights Watch, 2014).

\section{Marginalization and bureaucracy} authorities before proceeding legally. The authorities can refuse to register an association if they find that its content and/or objectives of its activities are inconsistent with "national principles, values, public order, public morals, and the provisions of applicable laws and regulations." Yet, Ben Nasser, a scholar at the Faculty of Law and Political Science, University of Ouargla acknowledges that these standards provide the authorities with a large boundary to hinder the recognition of any association (Ben Nasser, 2014). Interviewees shared their view about this problem as follows:

"In 2012, the new law of associations required the registered old associations to submit new applications, or they would be automatically dissolved. We faced administrative obstacles when we tried to comply with the new law. There are many associations the authorities refused to allow to have public halls to hold a general assembly or to hand them a receipt to register their documents." (Assoc.1) "... There are some associations that sent their documents via registered e-mail, but they did not obtain a receipt for the deposit, so they were unable to obtain any evidence that they had submitted their files within the specified deadlines." (Assoc. 1)

The authorities often violate the law and refuse to provide the deposit receipt when the founders of the societies provide registration documents, which leaves the organizations unable to prove that they have submitted their documents or that the waiting period has expired. Therefore, some associations that suffer from this status continued their work, but only on the margins of the law, and they were not able to open accounts, own offices or rent public halls to hold meetings. In addition, members of every unrecognized, frozen or dissolved association face the risk of imprisonment for up to six months for running any activity. In that case, Eric Goldstein, deputy director of Human Rights Watch's the Middle East and North Africa division said that "the Algerian authorities do not crush independent associations that directly concern them, but rather weaken and marginalize them by placing large legal barriers" (Human Right Watch, 2014).

Besides that, Law 12-06 gives the government the authority to freeze an association "in case of interference in the country's internal affairs or violating national sovereignty" (Law 12-06). The law also requires that any "cooperation in the framework of the partnership" between an Algerian association and international organizations obtain prior government approval, which gives the authorities broad powers to prevent many 
forms of cooperation between national and international societies. Eric Goldstein emphasizes that there is a clear contradiction between the association law as a theory and the Algerian authority's practice. On the one hand, Algeria calls for a free civil society, but on the other hand, it is violating Algeria's international obligations with regard to guaranteeing freedom of association. However, Goldstein stresses that the government should review this law by making it consistent with international standards and instruct the executive powers to stop arbitrarily obstructing associations' work (Human Right Watch, 2014).

Furthermore, associations expressed their dissatisfaction with the state, arguing that they have been marginalized inasmuch many of them have never been invited to festivals, cultural and tourism activities. According to their views, the state closes its outlets on associations generally, limiting the funding sources for associations, not allowing them to receive funds from outside sources, and not giving equal opportunities to highlight their capabilities in the field, which are all clear evidence of the "catastrophic" situation of associations in Algeria. As an interviewee expressed their dissatisfaction with the state:

".... If you visit the cultural events, you will find the same people every time, same

organizations, same associations. It's nepotism." (Assoc.2)

In the analysis of Boubacar Jamili, a professor of political sociology at the University of Constantine, the authority's appeal to civil society is not a new idea. Although the political system previously mobilized the idea for propagandistic ends by forming the "National Transitional Council" during the 1990s (Hodaaka, 2021), but in fact, government institutions intentionally excluded civil society institutions from many of their important discussions and decisions (Chaouch, 2015). Therefore, the state marginalized those institutions in terms of participation and shaping public policies. In this regard, the power elite in Algeria refers as "civil society" not to mediators between "the state" and "society", but instead to the dominant political player (Azaoui, 2014).

\section{Political willingness and tourism activity}

In addition to what have been mentioned, tourism stakeholders in Algeria acknowledge that the reality of tourism in Algeria does not encourage them to invest time and effort to work in the sector. As one of the interviewers stressed:

"Tourism is a complex industry made up of a number of different sectors (transportation, telecommunication, security, environment etc.). Those sectors are somehow still struggling in the case of Algeria." (TCA)

63 As Keenan (2005) emphasizes, Algeria's natural, historical, and cultural tourism components make it a world destination. However, Algerian tourism ranks very late in the Tourism and Travel Competitiveness Report. The World Economic Organization ranked it only $116^{\text {th }}$ internationally out of 140 countries in 2019 , and $12^{\text {th }}$ in the Arab world. In the same year, the tourism industry's direct contribution to the national GDP did not exceed $3.3 \%$, ranking $101^{\text {st }}$ globally, confirming that this industry is still far from world performance and does not reflect the reality of tourism assets of Algeria (WEF, 2019). Unfortunately, the number of foreign tourists has not exceeded 3.5 million annually for 20 years, and the number of arrivals to Algeria through travel agencies has not surpassed 2 million tourists (MTATF, 2019). In comparison, Tunisia reached out to 9.4 million, and Morocco recorded 13 million visitors for 2019 (Trading economic, 
2020). Interviewees expressed their disappointment with the development of the tourism sector in Algeria, saying:

"During the nineties of the last century and the beginning of the second millennium, the security situation in the country was behind the decline in the number of tourists, but with the improvement in the security conditions that Algeria witnessed in recent years, we have not seen improvement in the tourism sector, due to the lack of a clear and real strategy by the ruling authorities... no chance!" (T.A 2)

Tourism in Algeria is considered a politically sensitive subject. Beside the Algerian civil war of the 1990s, which had negative effects on the tourism sector, Algerian prime minister Ahmed Ouyahia indicated in a press conference in 2018 that Algeria still fears from terrorist threats from the South and the Sahel region, and that the situation in Libya, Mali, and other neighboring countries is still dangerous, and these conditions do not allow the revitalization of tourism in Algeria. This comment was received by the Algerian people as admission that Algeria's promotion of tourism, notably in the south, is primarily a political move rather than an economic initiative (Lahyani, 2018). This may explain the reason behind the setback of tourism in Algeria.

However, in light of the reality of tourism in Algeria and the amount of tourism investment accomplished, we can say that Algeria did not attach great importance to this sector in its economic policies. The tourism sector has been the least prioritized branch of the economy in term of investment made by the national government as it did not access 3\% from the total state budgets since the independence in 1962. The tourism budget for 2020 was estimated at 24 million euros, representing less than $1 \%$ of the total budget which consider really poor in comparison with other sectors like military and defense, which alone accounted for $25 \%$ of the total budget. According to the expert of tourism Said Boukhelifa, the tourism sector in Algeria is completely abandoned by the government, and the low budgets allocated to the sector are clear evidence of this (CNN Arabic, 2015).

Moreover, the Algerian government needs to invest in developing the appropriate infrastructure to enable tourism industry to compete internationally (Amish and Maddah, 2015). However, according to Ilyes Senoussi, president of the Algerian Syndicate of Tourist Agencies, Algeria still lacks the proper infrastructure (Tab. 1). The following table shows that there were only 13 five-star hotels in 2016, while the number of unclassified hotels was estimated at 160 , which reflects the weakness of accommodation in Algeria.

Tab. 1 Classification of hotels on the basis of stars system in Algeria

\begin{tabular}{|l|l|l|l|l|l|}
\hline Ranking & 2012 & 2013 & 2014 & 2015 & 2016 \\
\hline 5-star hotel & 8 & 8 & 8 & 8 & 13 \\
\hline 4-star hotel & 5 & 5 & 6 & 6 & 12 \\
\hline 3-star hotel & 38 & 38 & 39 & 39 & 51 \\
\hline 2-star hotel & 46 & 46 & 46 & 46 & 46 \\
\hline 1-star hotel & 116 & 149 & 149 & 158 & 158 \\
\hline
\end{tabular}




\begin{tabular}{|l|l|l|l|l|l|}
\hline Starless hotel & 127 & 156 & 156 & 160 & 160 \\
\hline
\end{tabular}

Source: Ministry of Tourism and Handicrafts, September 2019

67 According to the expert of tourism Said Boukhelifa, the problem of tourism in Algeria is a very complex one. Many literatures have focused on the obstacle of tourism in Algeria. A large number of researchers unanimously agreed that there is a lack of sufficient infrastructure (Eagan, 2018) and modern tourist facilities (Bouadam, 2011), accompanied by weaknesses in the capacity of hotel accommodation (Amish and Maddah, 2015) and in transportation and communication networks (Saudi et al, 2017.). Coastal pollution also has a negative effect on tourism (Tiabi et al, 2020), just like the lack-of marketing strategies for tourism, especially at the international level to attract foreign tourists (Zir, 2018), and the lack of qualification and professionalism of services and hotels. These are in addition to the visa procedure, that remains another obstacle for foreign tourists (Aouimer, 2020). Algeria is regarded as one of the most stringent countries in the world when it comes to getting a visa and allowing foreigners to enter its territory. Algeria only permits 11 countries to visit its territory without a visa, while Tunisia allows 72 countries and the number stretches to 90 countries in the case of Morocco.

\section{Socio-cultural barriers}

In addition to political obstacles, the interviewees also pointed out some socio-cultural barriers. Although those barriers are not easy to define, their analysis is a critical part of problem-solving, in terms of understanding all the obstacles that stand against the proper functioning of associations in Algeria. The study concluded two socio-cultural barriers: 1. political cultural imbalances and 2. the lack of interest on the side of Algerian society and the tendency of the Algerian government to do nothing for social circles.

\section{Challenges of political culture}

The prevailing cultural structure in Algeria is one of the main obstacles to civil society, and perhaps the most important feature of this aspect is the lack of political culture. Therefore, I asked the interviewees about why association registration requests are not approved, and what the reasons for dissolving associations are. The authorities expressed their opinion on this issue and accused associations with agendas that are not up to the required level and do not comply with the state's program. That is in addition to their lack of understanding of voluntary work and political work. As one of the interviewees said,

"The individual must be aware of his/her rights and duties, be aware of the laws and the prevailing system, and have confidence in his/her competencies and ability to influence the society. Some associations do not have a good work plan; some of them do not know what associative work means. And others do not differentiate between associative work and political parties. We have seen this in several experiences." (MTATF)

Political culture is considered part of the general culture (Somer, 1995), and its sources are multiple, including the historical heritage of society, the governing law, the behavior of individuals, and realistic beliefs that determine the state of political action. 
Individual acquisition of political culture contributes primarily to understanding how organizations and institutions work within the political system. In case of Algeria, the nature of Algerian politics after the independence in 1962 and the political experience with the one-party rule reduced individual and collective freedom and did not encourage the individuals to acquire a culture to qualified democratic values, which made the political culture described as a "sealed culture" (Merzouki and Sahrawi, 2016). However, Dalia Ghanem (2018) at the Malcolm Kerr-Carnegie Middle East Center argued that the Algerian society understands the nature of their political system, but the society lost trust in the authority to develop the country and improve their socioeconomic conditions (Ghanem, 2018). This level of confusion between society and authority has led to individuals evading their social reality and showing no willingness toward civic issues, associative work and volunteering (Omrane, 2019).

71 These problems are strongly intertwined with the lack of political trust. According to Hague, "trust" is a major factor in political culture, as its level determines the capacity of the state to function (Hague, 2017). Some literature refers to political trust as the citizens' belief that the government or political system will operate in a manner consistent with their expectations, and citizens who trust the government are more likely to comply with laws and pursue government initiatives. Putnam (1993) believes that citizens who trust are more likely to join a charity or spend some time on volunteering. Trust depends on the citizens' assessment of the extent of the authority's commitment to implementing what it promised and what it has confirmed to achieve. It is also a reflection of the performance of the government, parliament and president, and the effective management of the country's resources (Yang, 2005). If the authority fails to do so, then it loses its credibility and trust with the people. Recently, the political movement rejecting the nature of the prevailing regime proved that the Algerian reality is experiencing a deep crisis of trust between the people and the authority with all its political and administrative institutions. The authority in Algeria, with its various institutions, has not only failed in its politics, administration and programs, but has lost its sanctity and prestige and has not even succeeded in keeping its name, so it was called "Ei-saba", "The Gang", in the last anti-government protest of February 2019, in addition to its old title "le pouvoir", "the power", which was historically linked to the oligarchy that ran the country after the independence in 1962 (Yaylacı and Amasha, 2020; Ouaissa, 2020).

One of the results of this trust crisis is a general social skepticism about the whole political process and its electoral dates that became a subject of using terms such as "forgery," which is the opposite of "transparency" (Ben Sliman, 2013). Especially when many political actors that ruled and are ruling the country remain the same, which fueled the opposition's discourse that accused the authority of its lack of will to establish a democratic system with free civil society in which the first and last word returns to the people (Marzouki and Sahrawi, 2019). The lack of participation in elections is maybe a clear example of the lack of trust in the Algerian society (Meghzili, 2017). For comparison, election participation rate dropped in the 2019 elections to 39.8\% (BBC, 2019), while it was 51.7\% in 2014 and 90.2\% in 2009 (Alhurra news, 2019), because many citizens feel that the voting is useless. However, this kind of skepticism seems to stem from the deep understanding of citizens to their political nature as it covers not only aspects of their daily lives, but also their perceptions and belief that 
their participation is a futile process (Omrane, 2019). This context also makes necessary to investigate the reasons behind the lack of social interest in associative work.

\section{Apathy and inertia}

The analysis revealed allegations from the government to civil society organizations and vice versa. The impression of the lack of interests, and the inclination to do little for social circles were the major targets of these allegations.

On the one hand, governmental organizations accuse civil societies of not being ready and conscious of associative work as a concept. Today, the reality of civil societies' activity in Algeria asserts that the active contribution rate is meagre and does not extend to the required level of associative work. Still, a high percentage of the functional associations does not provide much, and their activity is rare and irregular. Besides, many organizations are criticized by the government for giving their activities a political nature, as some organizations did not hide their affiliation with certain parties (Mnouar, 2017), and some of them even were involved in election campaigns during the recent elections. The former President Abdelaziz Bouteflika powerfully expressed this position by saying: "Unfortunately, there are some associations that respond to other interests rather than the association objectives. If the religious associations, which are supposed to be a symbol of honesty, work for their personnel interests, what shall we say about other type of associations?" (Chaouch, 2015). Moreover, governmental organizations claim that civil society institutions seek to prioritize their own interests before the public interest, as most of them aim to take political positions in the future. The national Algerian daily newspaper, Ennahar, wrote a title in bold Businessmen, Contractors, and Association presidents on the top of the local election lists, referring to that many heads of associations landed at the top of political parties' lists (Mnouar, 2017). As an interviewee underscored,

" Civil society has abandoned many of its important tasks and turned into channels for the realization of projects of political parties. People cannot distinguish between the concept of associations and political parties due to the novelty and incomplete experience. Accordingly, despite the efforts of the Algerian state to eliminate the security and economic crisis, ... it cannot eliminate such mentalities that have been instilled in the minds of Algerian society." (MTAFT)

Concerning the sources of funding, the associations have been facing critical abuses. The state is cautious in the budget with regard to incomes and expenses, which requires a strict implementation of the law on associations and the transparency clause in the source of funding, but associations sometimes do not respect these. Some associations are not transparent even in the origins of their donations. This problem is not limited only to associations, but even to mosques which are considered the most trustful place for giving charities in Islamic countries. The media reported severe violations regarding Zakat ${ }^{3}$ funds, besides the scandals of some philanthropists that their donations to the mosques did not reach those who would have deserved them. As a result of these actions, society's "trust" has grown exceedingly weak, which deteriorated associative work (Annaser news, 2019). One of the interviewees at the National Tourism Board acknowledged that the practices of some associations is the reason why they are not approved:

"Nevertheless, the practices of some associations have demonstrated severe abuses that have lost their credibility, including those who have a political character and or those who deal with external parties that may affect national sovereignty and 
some others that have an ideological nature, adopt Western ideas that influenced the Algerian identity in general instead of investing in Algerian customs, traditions, and values in a way that serves the public benefit and contributes in solving youth problems. Note that only $45 \%$ of the entire organizations in Algeria are in accordance with the law." (ONT)

On the other hand, civil society accuses a state of being indifferent to meeting the needs and demands of the population, claiming the bureaucratic inertia of the various tiers of government. According to Ghanem (2018), civil society expresses its discontinuity with the state so that the individual has become apathetic toward civic issues, even as a participant. It is worth noting that the Algerian governmental research organization center in social and cultural anthropology submitted in 2015 a study that showed that the percentage of Algerians involved in voluntary associative work does not exceed a mere 3 to $4 \%$ of the total population (CRASC 2015). This explains the inability to determine the voluntary component, which is one of the essential elements of associations. The low involvement stems mainly from a lack of confidence in everything that symbolizes the state, especially associations and/or political parties (CNES, 2016). That has led to a gap between the state and people, especially young people. This debate coincided with the country's 2019 presidential elections that proposed President Abdelaziz Bouteflika (82 years old) for a fifth term. The event made many young people feel frustrated that the country is ruled by elderly people who do not necessarily understand the problems and aspirations of the new generation, and many scholars have linked this to another government crisis, the phenomenon of illegal immigration where young Algerians preferred to risk dying in boats towards Europe in search of better opportunities (Omrane, 2019). However, previous studies revealed that not only young people, but citizens in general are unwilling to participate in civic issues (Chaouch, 2015). It is widely agreed that the reasons for reluctance to participate are the lack of confidence in the ruling system; the ineffectiveness of political parties; a sense of inability to influence the political process; and a fear of politics in general (Burchardt et al. 1999). In addition to what has been indicated by some research that the reluctance to participate in politics is not only due to the citizen's belief that it is a futile process (Omrane, 2019) but also because of the lack of awareness and the absence of a media that could make citizens aware of the importance of associations and their role in strengthening societies and achieving development (Ghanem, 2018).

Moreover, most associations are based on the president's idea regarding the association's internal management, and this means that the director of the organization is the owner of the first and last decisions, while the rest of the members just carry out the implementation process (Belghit, 2015). In general, the internal environment of the associations often does not reflect an element of intellectual participation, team spirit or transparency. The tyranny exercised by most of the association leaders is among the negatives that have been entrenched into the minds of Algerian society, and the spread of this negative phenomenon can be traced back to the absence of a good example in leadership (Chaouch, 2015). Unfortunately, the behaviors of many of those at the top of the pyramid in many governmental organizations do inherit only broken people who are not confident, indifferent, inefficient and un-loyal to the interests of the organization. 


\section{Conclusion}

78 This paper contributes to broader scientific debates on the obstacles to civil society organizations in tourism development. Up to my best knowledge, the current study is the only one that has attempted to empirically explain the relation of the state and civil society organizations, as well as its implications in the Algerian context, specifically from the perspective of tourism development. The article simply assists tourist managers and planners in the study region, as well as other localities with a similar feature, in properly understanding the barriers to association in tourism development. For its methodological approach, this paper contributes to bringing together stakeholders' perspectives from the national to the local level, citing various reasons for local community failure, including legislative, political and socio-cultural obstacles, among others, which many researchers have not mentioned before.

To sum up, civil society in Algeria has gone through several pivotal stages characterized by specific socio-political factors that shaped its features according to power relations in each historical period. Before independence, and with the issuance of the first law of associations in 1905, Algerians were allowed to form associations and organizations of a social, cultural and even political nature. These helped preserve the Algerian people's privacy, defend their identity and work to confront the colonizers. And this provided clear evidence of the nature of civil society and its role in reviving the features of Algerian society and expelling the colonizers.

However, the awareness and patriotism these organizations gained their strength from weakened after Algeria's independence in 1962. The modern, independent Algeria sought to build national sovereignty, first on basis of the principles of a socialist system, and then, after 1990, along the principles of a capitalist system. During these periods, the civil society acquired a diverse structure, as it witnessed many changes and reforms, whereas remaining subordinated to the state. However, despite the multitude of reforms since 1962, and the large number of civil society organizations, civil society in Algeria has not been able to achieve a high level of effectiveness. This is due to many obstacles, partly stemming from the government and its practices, partly from weak institutional structures, as well as the lack of civic culture in Algerian society in general.

81 As my results revealed, the low level of associations' activity in Algeria results from a number of factors, including historical, political, economic, cultural and social factors. The ruling regime in Algeria grew up with historical events that affected its legitimacy. The association movement arose and grew in Algeria due to the crises and setbacks of the ruling authority and the anger of the local community. Today, civil society is considered a parasitic organism by the power elites that came and was imposed by modern ideologies to establish democracy. In fact, civil society has been exploited by the ruling class since 1962 and continues to do so.

From a legislative point, the structure of civil institutions in Algeria generally lacks independence from the state. This matter is primarily due to the state's dominance for decades over every voluntary work outside the scope of a single ruling party. State domination has entrenched obedience and subordination to civil society organizations in general, even those who are supposed to be the opposition. Most of these associations, for example, depend on the state financially and are unable to find regulatory frameworks for financial independence, which makes them compelled to 
align themselves with the authority to obtain its share of assistance and support. This was shown by my analysis of the associations law in Algeria. Although it may appear from the initial reading that the new law of 2012 came to enrich the old law of 1990, the new law is actually more stringent and restricted the freedom of associative work. The law of 2012 sought to tighten procedures in establishing associations and impose tight control over their activities, financial resources, and their relations with political parties and various international associations, which negatively affected the performance of associations in Algeria. The research results made it clear that the regime imposes its control on associations by creating a compulsive legislative and legal apparatus that nullifies all organizational attempts that want to be active outside the regime's institutional framework and international interests.

From a political point of view, the Algerian government has never viewed civil society as a partner in development that complements its deficiencies. Rather, it has always viewed civil society as a competitor that must be curbed. This made civil society with its various formations unable to play its developmental role in general. Despite the many "reforms" implemented to establish the foundations of civil society organizations, the reality remains far from expectations. It is impossible to talk about a real civil society in the absence of democracy, and the Algerian case is consistent with what Tocqueville has approved. Furthermore, the relationship between the state and associations is a relationship of domination, as Gramsci explained. The Algerian government does not use associations to control society but rather uses its authority to restrict associations and prevent them from growing and developing and therefore control the society. Thus, the state's relationship with civil society is closer to a tyrannical relationship in which the state seeks to control civil society. It is true that civil society can contribute, in one way or another, to advancing tourism development in Algeria by consolidating the tourism culture and actively contributing to promoting tourism and achieving security and stability. However, the state's short view of tourism programs and the lack of a clear and common tourism program do not encourage the local community to invest in tourism. In the same context, we can conclude that civil society is invisible for to the manifold restrictions by the political regime, which surround all its operations.

From a socio-cultural view, the case of Algeria showed that associations sometimes deviate from the spirit of civil society and the law in general. Some associations in Algeria turned into private institutions of an economic and political nature, serving the narrow interests of their leaders. These clear differences between the stated goals and the actual activities of some associations worry the regime and hinder the country' sovereignty. However, despite the law's requirement that associative activity and political practice have to be separated, this remains a political statement in Algeria. A remarkable example for that is the organizations' support during presidential elections in exchange for official advantages. This is in addition to the competition among certain leaders of associations for future political positions. These made certain associations "in some ways" a "competitor" in the eye of the authority, which are competing with the authority for governance, and "opportunistic" in the eye of many citizens, where association leaders just seek to take advantage of individuals to achieve their own goals. This conflict of interests created a kind of mistrust in society for everything that seems connected to the authority, including political parties, unions 
and associations, where individuals tend to see their potential participation unproductive and pointless.

\section{BIBLIOGRAPHY}

Addi, L (2011). Obstacles to the formation of civil society in Algeria, La Découverte, 2011. pp. 369-384. https://halshs.archives-ouvertes.fr/halshs-00596377

Alhurra news, (2019). Algeria, lowest turnout in multi-presidential elections. Dec, 2019. https:// arbne.ws/3DiHcDm

Amish and Maddah, (2015). the challenges of hotel establishments in supporting the tourism industry case: Algeria. Economic Studies Journal. 9 (1). pp. 165-180. https://www.asjp.cerist.dz/en/ article/86871

Annaser news, (2019). Randomness and fraud stifle charitable work. Annaser news, Mars, 2019. https://cutt.ly/JEBigfP

Aouimer, I. (2020). Does Algeria refuse to be a tourist country? Independent news in Arabic. 5 July 2020. https://cutt.ly/FEV6Ifa

Aref F, Gill SS, Farshid A (2010). Tourism development in local communities: As a community development approach. Journal of American Science. 6, pp.155-161. http:// www.jofamericanscience.org/journals/am-sci/am0602/26_1215_Communities_am0602.pdf

Azaoui, H. (2014). Associative movement in Algeria between efficiently and formal development performance. https://www.univ-chlef.dz/eds/wp-content/uploads/2016/06/article-18-N3.pdf

Baouali, R; Baziz, A; Hadjiedj, A. (2019). Comparative competitiveness indicators, which ranking for the Algerian tourism? GeoJournal of Tourism and Geosites. pp. 133-145. http://

gtg.webhost.uoradea.ro/PDF/GTG-1-2019/GTG-1-2019.pdf

Ben Nasser, B. (2014). The Law of Associations in Algeria - A critical reading of Law 12/06. Politics And Law Notebooks Journal, 6 (10). pp. 253-266. https://www.asjp.cerist.dz/en/article/52357

Ben Nefissa, S. (2000) Powers and Associations in the Arab World. Paris: CNRS Edition, 2002. https:// books.openedition.org/editionscnrs/40062?lang=en

Ben Sliman, (2013). The impact of the electoral system on parties in Algeria 1989 - $2012 \mathrm{https}: / /$ bit.ly/3aeclX6

Bendimerad, S., Chibani, A. \& Boussafi, K. (2019). Boom associatif en Algérie: réalité ou illusion démocratique? RECMA 354, pp. 42-57. https://doi.org/10.3917/recma.354.0042

Bouadam, R. (2011). The national strategy of tourism development in Algeria: issues, opportunities and limitations. Review of Applied Socio- Economic Research 2. pp. 23-37. http:// reaser.eu/scripts/form/upload/6Rev2_4_Bouadam.pdf

Burchardt, T., Le Grand, J. and Piachaud, D. (1999). Social Exclusion in Britain 1991- 1995", Social Policy and Administration 33(3), pp. 227-244. https://doi.org/10.1111/1467-9515.00148 
Buttigieg, J. A. (1995). Gramsci on Civil Society. Boundary 2, 22(3), 1-32. https://doi.org/ $10.2307 / 30372$

Cavtorta, F; Durac, V (2011). Civil Society and Democratization in the Arab World, Routledge, 2011. https://www.routledge.com/Civil-Society-and-Democratization-in-the-Arab-World-TheDynamics-of-Activism/Cavatorta-Durac/p/book/9781138780224

Chaouch, E, J (2015), The reality of civil society in Algeria: a field study for associations. of the city of Biskra. https://core.ac.uk/download/pdf/35402895.pdf

Clayton, A. (1996) NGOs, civil society and the state: building democracy in transitional societies. Intrac Oxford. https://doi.org/10.1080/0961452961000157854

CNES (2016). National Report on Human Development 2013-2015, What place for young people in the perspective of sustainable human development in Algeria? National Economic and Social Council. https://planipolis.iiep.unesco.org/en/2016/rapport-national-sur-le-developpementhumain-2013-2015-7111

CNN Arabic, (2015). Tourist expert: Algerian hotels are the most expensive in the Maghreb due to the lack of beds. https://arabic.cnn.com/world/2015/09/01/algeria-tourism

CRASC, (2015|). Center for Research in Social and Cultural Anthropology Algeria. https:// www.crasc.dz/index.php/en

Derras, O. (2007). The associative phenomenon in Algeria. Algiers. Frederich Ebert Stiftung, 2007. https://library.fes.de/pdf-files/bueros/algerien/05046-text.pdf

Eagen, K (2018). Algerian Tourism Faces Several Problems, Tourism News Review, Reported Voice of Tourism, Nov 2018. https://www.tourism-review.com/algerian-tourism-deals-with-severalissues-news 10810

France 24 news. (2011). Sharp controversy over a new law for associations in Algeria. Dec, 2011. https://cutt.ly/3EV9wMW

France 24, (2011). Sharp controversy over a new law for associations in Algeria. https://bit.ly/ 3ovn5xA

Ghanem, (2018). Limiting Change Through Change: Beyond the Permanence of the Algerian Regime. Carnegie middle east center. https://carnegie-mec.org/2018/05/08/ar-pub-76277

Gramsci, A (1971). Selections from the Prison Notebooks of Antonio Gramsci. New York: International Publishers, 1971. https://abahlali.org/files/gramsci.pdf

Green, C. (1993). Advanced capitalist hegemony and the significance of Gramsci's insights: a restatement. Social and Economic Studies, 42(2/3), 175-207. http://www.jstor.org/stable/27865900

Hague, R. Martin, H; John, McC (2017). Political science: a comparative introduction. New Delhi: Red Globe Press, pp. 200-214. https://www.worldcat.org/title/political-science-a-comparativeintroduction/oclc/945797135

Hanafi, F. (2020). Associations financial resources censored under Law 12/06. Jil Journal for Legal Depth Research. 43. p75. https://bit.ly/3ioQcyH

Hodaaka, A, H. (2021). Civil society in Algeria. Does the authority want it as an alternative to the parties? https://bit.ly/3mkaVou

Human right watch (2014). Algeria: Bureaucratic Ploys Used to Stifle Associations. https:// www.hrw.org/news/2014/03/30/algeria-bureaucratic-ploys-used-stifle-associations 
Jamal, T, Stronza, A (2009). Collaboration theory and tourism practice in protected areas: Stakeholders, structuring and sustainability. Journal of Sustainable Tourism, 17(2). pp.169-189. https://doi.org/10.1080/09669580802495741

Keenan, J. (2005), The development or redevelopment of tourism in Algeria, Intellect 2005. pp. 159-173.

Lahyani, O. (2018). Closing the Algerian Sahara: Fear of Terror or Other Motives? Elaraby news. 1 May 2018. https://cutt.ly/Nd7oOpT

Lahyani, O. (2018). The Secrets of the Algerian Desert. Elaraby. 6 February 2018, https://cutt.ly/ ld7oZxw

Law 12-06, (2012). Algerian law of Association. http://www.apn.dz/AR/images/ textes_reformes_politiques_ar/11-loi_12-06.pdf

Law 90-31, (1990). Algerian law of Association. http://menarights.org/sites/default/files/ 2016-11/ALG_LawOnAssociation_AR_1.pdf

Maouchi, A (2020). Freedom of association in Algeria under the French occupation (1830-1930). Journal of Historical Research. 4 (1), pp. 121-148. https://www.asjp.cerist.dz/en/article/115103

Meghzili, N. (2017). The crisis of political participation in Algeria. Arabic democratic center. April, 2017. https://bit.ly/3ovYJU7

Merzouki, O; Sahrawi, M. (2016). Political culture and civil society in Algeria: the problematic relationship. Al-Bahith Journal for Academic Studies, 3(1), pp. 136-155. https://www.asjp.cerist.dz/ en/article/6464

Ministry of tourism in Algeria, (2021). https://www.mta.gov.dz/?lang=en

Mnouar, A (2017). Businessmen, wrestlers and contractors preside over the lists of localities! Ennahar news, Sep, 2017. https://cutt.ly/LEV1qsf

Muganda, M., Sirima, A., \& Ezra, P. M. (2013). The role of local communities in tourism development: Grassroots perspectives from Tanzania. J Hum Ecol, 41(1), 53-66. https://doi.org/ 10.1080/09709274.2013.11906553

Northey, J (2017), Associations and Democracy in Algeria'. Democratization Journal, 24 (2), pp. 209-225 https://doi.org/10.1080/13510347.2016.1144590

Omrane, M, (2019). Youth civic and political participation in Algeria: Issues and challenges, in Sanchez-Montijano, E., Sanchez Garcia, J., (Ed.), Youth at the Margins, Perspectives on Arab Mediterranean Youth, London: Routledge, pp. 30-48.

Ouaissa R, (2020). Algeria: Between Transformation and Re-Configuration. Re- configuration, pp. 54-61 https://doi.org/10.1007/978-3-658-31160-5_4

Putnam, Robert D. 1993. Making Democracy Work: Civic Traditions in Modern Italy. Princeton: Princeton University Press. https://press.princeton.edu/books/paperback/9780691037387/ making-democracy-work

Rahal, M. (2017). 1988-1992 Multipartyism, Islamism and the descent into civil war. Patrick Crowley. Algeria: Nation, culture and transnationalism. 1988-2015, Liverpool University Press, 2017. pp. 1-29. https://hal.archives-ouvertes.fr/hal-01654761/document

Saudi et al, (2017). the role of tourism transport in revitalizing and activating the tourism sector in Algeria to achieve development. Al-Aseel Journal of Economic And Administrative Research. 1 (1), pp. 187-20 https://www.asjp.cerist.dz/en/article/79976 
Somers, M. (1995). What's Political or Cultural about Political Culture and the Public Sphere? Toward an Historical Sociology of Concept Formation. Sociological Theory, 13(2), pp. 113-144. https://doi.org/10.2307/202157

Stoney, C; Winstanley, D. (2002). Stake holding: confusion or utopia? Mapping the conceptual terrain. Journal of Management Studies, 38(5), 603-626. https://onlinelibrary.wiley.com/doi/abs/ $10.1111 / 1467-6486.00251$

Taibi et al. (2020). Micro- and macro-plastics in beach sediment of the Algerian western coast: First data on distribution, characterization, and source. Marine Pollution Bulletin 165(11):112168 https://doi.org/10.1016/j.marpolbul.2021.112168

Terranova, B. (2011). Algeria: The Obstacles to Democracy. E-International Relations. https:// www.e-ir.info/pdf/12285

Tocqueville, Alexis de. Democracy in America. London: Everyman's Library, 1994 [1840]. https:// www.amazon.com/Democracy-America-Everymans-Library-Tocqueville/dp/0679431349

Tosun, C (2000). limits to community participation in the tourism development process in developing countries, Tourism Management, 21(6), pp. 613-633. https://www.researchgate.net/ publication/

223375184_Limits_to_Community_Participation_in_the_Tourism_Development_Process_in_Developing_Countries

Trading economic, (2020). https://tradingeconomics.com/search.aspx?q=algeria

UN news, (2013). In university lecture, ban notes shared responsibility to protect rights, freedoms. https://news.un.org/en/story/2013/08/447722-university-lecture-ban-notes-sharedresponsibility-protect-rights-freedoms

WEF, (2019). The global competitiveness report 2019. https://www3.weforum.org/docs/ WEF_TheGlobalCompetitivenessReport2019.pdf

WTTC, (2019). Travel \& tourism city travel \& tourism impact 2019. https://wttc.org/Portals/0/ Documents/Reports/2019/

City\%20Travel\%20and\%20Tourism\%20Impact\%20Graphics\%20Report\%20Dec\%202019.pdf? ver=2021-02-25-201320-033

Yang, K. (2005). Public Administrators' Trust in Citizens: A Missing Link in Citizen Involvement Efforts. Public Administration Review, 65(3), 273-285. http://www.jstor.org/stable/3542504

Yaylacı and Amasha (2020). Islamist Movements and Parties in The Algerian Uprising. Al Sharq Strategic Research. https://research.sharqforum.org/2020/07/10/islamist-movements-andparties-in-the-algerian-uprising/

Zir, R (2018). The contribution of tourism marketing to the development of tourism in the Arab world, a comparative study of Algeria, Tunisia, and the United Arab Emirat. Doctorate Thesis 2018 https://core.ac.uk/download/pdf/196257633.pdf

\section{NOTES}

1. The French Law of Associations, issued on July 01, 1901, is a historical landmark for freedom of association in France. This law came after a long delay compared to Western countries that recognized freedom of association during the nineteenth century. In Germany, for example, the principle of freedom of association was enshrined in 1818, and in Belgium in 1830, while in England, freedom of assembly is rooted in the depth of the history of this country. In the US, the 
movement of gathering employees was formed in 1880, and the first American association for municipal affairs in 1891.

2. The 1988 October Riots were a series of violent demonstrations by Algerian youth, starting on 5 October 1988 and ending on the 11th. The riots indirectly led to the fall of the country's oneparty system.

3. Zakat is a mandatory charitable contribution in Islam religion, often considered to be a tax based on the value of one's all possessions.

\section{ABSTRACTS}

This paper aims to investigate the challenges civil society organizations are facing in Algeria, with a special focus on tourism development. On basis of a stakeholder approach and the Gramscian notion of civil society as a field of ideological competition, the study investigates the main features of tourism associations along with the obstacles hindering their proper performance. The backbone of the study is formed by a detailed qualitative investigation that includes in-depth interviews with fifteen governmental and non-governmental institutions related to tourism in Algiers, the capital city of Algeria, as well as the analysis of secondary materials like media reports, press releases, laws, and statistics. The findings reveal three main challenges that limit the role of tourism associations in Algeria. These challenges are closely related to three factors: (1) Legislation, more specifically the laws on associations that hinder the proper work of associations. (2) The Algerian political regime and its merely tyrannical relationship with civil society organizations, which the regime seeks to dominate in order to control civil society, instead of considering them as potential partners in fixing actual challenges for tourism development. (3) Socio-cultural factors, especially the lack of trust in institutions, which makes a great part of society unwilling to get involved in civil society organizations.

Cet article vise à étudier les défis de la société civile organisée en Algérie à partir du développement du tourisme. Basée sur l'approche des groupes d'intérêt et le concept gramscien de société civile en tant que champ de compétition idéologique, on identifie si les principaux caractéristiques des associations touristiques que les obstacles qui entravent son progrès. Notre article est formée par une recherche qualitative détaillée dans laquelle on mobilise des entretiens avec quinze institutions gouvernementaux et non- gouvernementaux liées au tourisme en Argel, en plus de matériaux sécondaires tels que rapports de communication sociale et de la presse, lois et statistiques. Nos résultats montrent trois défis qui limitent le rôle des associations touristiques en Algérie: (i) la législation, notamment les lois sur les associations; (ii) le régime politique algérien, dont le rapport tyrannique aves les organisations de la société civile vise à les contrôler à l'invers de les considérer en tant que des alliés potentiels face à l'identification des vraies défis ; (iii) des facteurs socio-culturels, surtout la manque de confiance par rapport les institutions. Le résultat, c'est qu'une grande partie de la société n'est pas disponible à s'engager dans les organisations de la société civile.

Esse texto investiga os desafios enfrentados pela sociedade civil organizada na Argélia a partir do desenvolvimento do turismo. Baseado na abordagem dos grupos de interesse e na noção gramsciana de sociedade civil como campo de competição ideológica, identificamos tanto as principais características das associações turísticas quanto os obstáculos que dificultam seu bom 
desempenho. A espinha dorsal do estudo é formada por uma investigação qualitativa detalhada que inclui entrevistas aprofundadas com quinze instituições governamentais e nãogovernamentais relacionadas com o turismo em Argel, bem como a análise de materiais secundários como relatórios dos meios de comunicação social, comunicados de imprensa, leis e estatísticas. Os resultados revelam três desafios principais limitadores do papel das associações turísticas na Argélia: (1) a legislação, mais especificamente as leis sobre associações que dificultam o bom trabalho das mesmas; (2) o regime político argelino, cuja relação tirânica com as organizações da sociedade civil visa controlá-las e não considerá-las como potenciais parceiros no reconhecimento de desafios reais para o desenvolvimento do turismo; (3) fatores sócioculturais, especialmente a falta de confiança nas instituições, o que faz com que uma grande parte da sociedade não esteja disposta a envolver-se em organizações da sociedade civil.

Este texto tiene como objetivo investigar los desafíos que enfrenta la sociedad civil organizada en Argelia, con un enfoque especial en el desarrollo del turismo. Con base en un enfoque de los grupos de interes y en la noción Gramsciana de la sociedad civil como campo de competencia ideológica, el estudio investiga las principales características de las asociaciones turísticas junto con los obstáculos que dificultan su buen desempeño. La columna vertebral del estudio es una investigación cualitativa detallada que incluye entrevistas en profundidad con quince instituciones gubernamentales y no gubernamentales relacionadas con el turismo en Argel, la capital de Argelia, así como análisis de materiales secundarios como informes de los medios, comunicados de prensa, leyes y Estadísticas. Os resultados revelam três desafios principais que limitam o papel das associações turísticas na Argélia: (1) Legislación, más específicamente las leyes sobre asociaciones que obstaculizan el buen trabajo de las asociaciones; (2) El régimen político argelino y su relación meramente tiránica con las organizaciones de la sociedad civil, que el régimen busca dominar para controlar a la sociedad civil, en lugar de considerarlas como socios potenciales en la solución de desafíos reales para el desarrollo del país; (3) Factores socioculturales, especialmente la falta de confianza en las instituciones, que hace que gran parte de la sociedad no esté dispuesta a involucrarse en organizaciones de la sociedad civil.

\section{INDEX}

Palabras claves: turismo; grupos de interes; sociedad civil organizada; asociaciones; Argelia.

Palavras-chave: turismo; grupos de interesse; sociedade civil organizada; associações; Argélia.

Mots-clés: tourisme ; groups d'intérêt ; société civile organisée ; associations ; Algérie.

Keywords: tourism; stakeholders; civil society organizations; associations; Algeria.

\section{AUTHOR}

\section{SOUFIANE BOULASSEL}

ELTE Eötvös Loránd University, Institute of Geography and Earth Sciences, Department of Social and Economic Geography, Budapest, Hungary. E-mail: Soufjan@caesar.elte.hu 